\title{
STUDENTS' CONSCIOUSNESS ON LEARNING GRAMMAR IN ENGLISH TUTORIAL CLASS
}

\author{
Vilya Lakstian CM \\ vilyalakstian@gmail.com \\ IAIN Surakarta
}

\begin{abstract}
Students in higher education are ordered to be competent in English. This happens as the response of high requirement in using English for larger uses nowadays. Consequently, higher education nowadays provides English tutorial to prepare the students to be competent English users, including mastering grammar. This research was conducted in order to discover students' participation, grade, and score improvement as the aspects of applying consciousness towards English grammar.The research adopted mixed method approach. The researcher collected the data by observation, tests, and questionnaires. The participants were the students in English tutorial class from the Faculty of Islamic Economics and Business and the Faculty of Islamic Education and Teacher Training. The objective of this research are to monitor the students' sincerity working on the learned lessons and to make senses their performance with the supports of their assessment records. The results showed various dynamics on the students' existence being part in the lessons. High participation was done by the students along with various grades. All observed students showed positive self-correction and increasing score improvement with their heterogenous mechanisms. This research notices that the students have motivation to be mastered, but their experience and exposure on English grammar affect their assessment results. However, the data reveal that their efforts remain improved as reflected in their track records in the lessons.
\end{abstract}

Keywords: consciousness, grade, grammar, improvement, participation

\section{INTRODUCTION}

In the era of globalization, English plays important role as a lingua franca that connects people around the world. In business for example, people communicate in English to reach their goal effeciently (Watson in Kompas, 2017). To respond ths challenge, some efforts are done by people to be competent English users, for instance: attending English course and workshop.

Some factors underlie people's performance in decision, expectation, ongoing course, and result in order to utilize English skills.The role of attitude towards participating in English course is provided by Serin, Serin, \& Ceylan (2010). They find faculty background, where their current education are in, affect positive and negative attitudes. Those attitudes are also found in relation with students' success while they were in high school. Liu et. al. (2011) do inquiry on needs analysis towards 972 non-Englishmajor EFL students in Taiwan with three important issues released by Hutchinson and Waters (1987) including necessities, wants, and lacks. Needs analysis underlie detail information by non-English-major EFL participants in the course so that instructors are able to know their motivation and to gain strategy for better teaching.Serin, Serin, \& Ceylan (2010) and Liu et. al. (2011) give relevant references for assessing English course.

In IAIN Surakarta context, Language Development Center (Pusat Pengembangan Bahasa or $\mathrm{P} 2 \mathrm{~B}$ ) was establishedto fulfill the requirement of foreign language competency. $\mathrm{P} 2 \mathrm{~B}$ is ordered to provide language course 
(henceforth, called as language tutorial as the teacher is termed 'tutor' in P2B, and the class schedule is out of students' majored-department) for students and workshop for languagemajor and non-language-major lecturers.

P2B's English competency assessment is provided through Test of Standard English (TOSE). Before taking the test, the students from all faculties in IAIN Surakarta are obliged to participate in the language tutorials by tutors for 12 meetings.

In order to monitor students' participation in the English tutorial, it is required to appraise their progress. It is important for comprehending their development in the course. This way can track the success of exposing students with English lessons which can be utilized by tutors and P2B.

It is also helpful to know their consciousness in participating the English tutorial. The consciousness also includes their motivation towards the tutorial and its results. Nelson (2011: 19) refers language, self, and consciousnes to human's thinking theory in relevance for making sense. For example, positive valuation on the material may lead to good progress on their comprehension, even participation in the class and vice versa. It is in the paths of comprehending how they give reaction from stimuli as Block (2013) saying consciousness as the scheme system of perception, apreciation, and action which enable people to have role or performance from practical knowledge based on identification and recognizing stimuli by condition and custom.

The researches conducted by Serin, Serin, \& Ceylan (2010) and Liu et. al. (2011) show some conditions happening in English Language Teaching (ELT) supported by education variables carried by students such as their education background. However, the progress on ELT need to be in-depth exploration. Diverse background of students have not been tracked on their progress to monitor the students' conciousness to master learned lessons. The exploration of this idea attracts the presence of this research.

For listing research gaps deeper, the researcher consider other related researches on teaching English grammar. In the perspective of teacher on the learning progress, the research conducted by Jean \& Simard (2011) discovers high school students' belief on grammar, especially grammatical accuracy and corrective feedback. Then, Ahmad, Abdullah, \& A Ghani (2014) provide the background of school system in high school affects also in establishing students' attitude and motivation towards English.

It is different for students taking higher education. They are prepared for professional working. Curiosity comes by asking if they remain keeping their attitude as they did in high school because their timing is now more limited to realize their skill in working. In this period, they need more efforts to face this kind of language skill required in modern and global job networking.

Students' consciousness and progress in ELT explored in this research arouse the idea of identity. It is how the students manage awareness in considering themselves and surroundings (including their future). This identity issue affects on their performance. It is like the concept introduced by WEB Du Boisin advaced way which is named double conciousness. It isresearched by Valdez (2015). The research explores undergraduate Chinese international students encountering American classrom practices and faculty.

All issues above attract finding students' stance on class participation. English tutor also needs to know students' progress. Score remains one of indicator to render students' improvement, but it continues to the question about providing learning outcome more real.Then, it is not only 
limited to final score. Although some students do not have changing score drastically, small number of point can reflect as an advance. It should be appreciated. It is crucial on learning English grammar. Formality in English grammar is required for reaching English skill. This statement is found by quessionaire to the students of P2B English tutorial classes which the researcher took role as the tutor. 98,2\% students agree that English grammar is important for them. 92,9\% students also agree that being skilled on English grammar is the indicator of being competent in using English.

In implementing this case, research is needed. Because class consists of students with various backgrounds, this curiousity is then conducted by providing students' background including job domain preference, department, and expectationtowards English inquiried from the preliminary meeting. Those three students' backgrounds come from considering consciousness as reflect belief up to identity in previous researches above. In the context of ELT, this research is then connected to the students' assessment records.

\section{RESEARCH METHOD}

This research is done quantitatively and qualitatively. Source triangulation is held by tests and students' turn in provided by Edmodo, the students' online platorm. Pre and post tests are done by the researcher to know their progress from early meeting up to the last. The researcher does method triangulation using participative observation, questionnai-re, and document analysis. Participative observation is done for getting real class condition and activity where the researcher was the tutor. The questionnaires are provided for the students to get their learning background and motivation. (The questionnaires are available in these links: (https://goo.gl/forms/2WfRWNy4OML3ClbI; https://goo.gl/forms/GKDYFQLE1owtQcYW
2). They were provided from preliminary and last meeting in order to get in-depth findings. This way enables considering other factors, even motivation influencing the English course results. The students' assessment records, the records' analysis into classifications, and their calculation for domain up to componential analysis are treated as document analysis.

Collecting data was done in 12 meetings of P2B English tutorial class which include grammar focus.The researcher limits his research on grammar mastery along with their motivation and expectation toward using English. Furthermore, there are criteria leading this research into purposive sampling in order to get the data. First, the participants are the students participating P2B English tutorial class. There are 30 students consisting of 7 male and 23 female students. Second, the participants are limited only to those who are registered as the students under supervision of the researcher (also as the tutor). Third, the students are the data source who are involved actively plus completely in data collection from the preliminary meeting up to the last together with their participation on the first and last meeting questionnaires, pre-test, learning activity, and post-test. Forth, the tests are taken from the students passing those sequences. The tests are facilitated by Edmodo. This way performs effort to present valid data source and collection functioned as research triangulation. It helps researcher find relationship after the previous steps. When the relevant data have been selected, the researcher does taxonomy analysis as the step for classifying the data. Then, he connects all components for componential analysis which is improved into cultural theme analysis for finding relationships as Spradley (2007) formulates data analysis technique. 


\section{RESEARCH FINDINGS}

Discovering students' backgrounds is required for preparing them in encountering lesson. Their experiences involve - even attract, their attention on getting knowledge well to their mind. It is also in the way of recharge their motivation that learning progress will be useful for their life goal.

Individual students bring their own influential characteristics (such as ability beliefs, personal interest, values) into the classroom up to finally presenting constructive autonomy motivation in learning (Jang 2008, 799). It is needed to observe students' future shows clearly with the real context of their education departments, their interest on other domains such as: creative industry, public relation, administration, and consultant, should be appreciated.

On the other side, the researcher also investigates how much their interest to English. $65 \%$ of students have great interest to be professional with English while 22,5\% just want to know and to use English. Then, 12,5\% use English to fulfill requirement and term for their study. This finding shows that the students do not merely study English for obeying obligation from

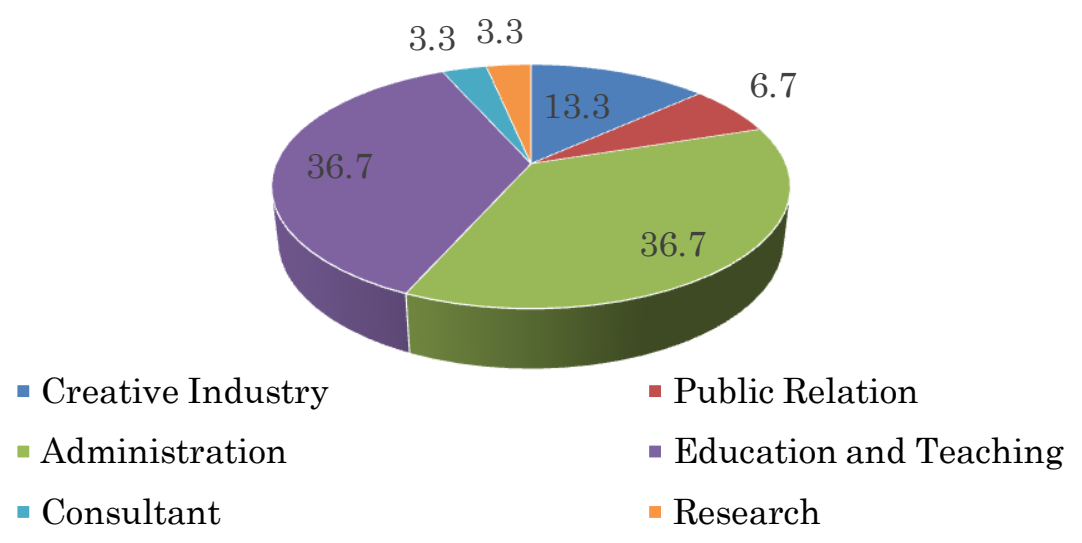

Chart: Students'job domain preference

goals in order to make students take stance on the subject and learning process. The researcher provided questionnaire for preliminary observation to students as the participants in the class.

The preliminary questionnaire include students' interest on their future job. The researcher involved in the English tutorial class, which covered two different faculties. They are the Faculty ofIslamic Education and Teacher Training and The Faculty of Islamic Economy and Business, their job domains are various. The chart below shows students' job preference.

Most students prefer education and teaching, and administration for their future jobs. It is relevant with their current faculties. Although this finding their campus. It presents that the students have consciousness enough to be part in English learning like those who are desired to be professional and only want to know English are combined.Those compositions includes their participation in the English tutorial class. When P2B English tutorial period which they were involved, focused more on grammar, it is significant to train them for being able in formal written English for real. There is formality as the criteria on written language dominantly with its application for office use.

To take more depth in students' consciousness, it is crucial to monitor students' participation in the class. There were some activities held to present learning progress. Besides 
learning material, test is important to know students' comprehension. Pre and post test in the class were done totally in eight times. There are many topics taught in the class as provided in the module issued by P2B IAIN Surakarta (2016). Then, the researcher classified them into for major lessons as the result of classifying the topics into macro lessons. Pre- and posttests were conducted. They were subject-verb agreement, adjective and adjective phrases, paralelism, and relative clause (visualized in Table 3).

\section{Future Jobs and Students' Efforts on Grammar}

In the preliminary explanation above, there have been mentioned that first observation finds students' attention towards using English. The concerning in education and teaching need to have better participation as reflected from grammar tests on valuating the major grammar topics. However, in the perspective of grading on grammar tests, they have good percentage. It is averagely $65,6 \%$ from excellent score, better than grade percentage by administration. This finding is supported by score imporvement which is slightly higher. If it is connected to their faculty, it may refer to the presence of English lecture in their depatments. So, they have been exposed with English knowledge. Although their participation is lower than administration job preference, they can prove their ability more than sufficient grade. It needs respect to those chosingadministration. Their

Table 1: Average Students' Involvement Based on Job Domain Preference

\begin{tabular}{lcccc}
\hline $\begin{array}{c}\text { Job Domain } \\
\text { Preference }\end{array}$ & $\begin{array}{c}\text { Number of } \\
\text { students }\end{array}$ & $\begin{array}{c}\text { Participation } \\
\text { (\%) }\end{array}$ & $\begin{array}{c}\text { Grade } \\
\text { (\%) }\end{array}$ & $\begin{array}{c}\text { Score } \\
\text { Improvement }\end{array}$ \\
\hline Creative Industry & 4 & 81,3 & 49,7 & 3,3 \\
Public Relation & 2 & 100,0 & 45,9 & 7,0 \\
Administration & 11 & 90,9 & 49,3 & 4,7 \\
Education and & 11 & 86,4 & 65,6 & 5,0 \\
Teaching & 1 & 100,0 & 74,3 & 7,0 \\
Consultant & 1 & 100,0 & 66,2 & 5,0 \\
Research & 30 & 558,5 & 351,1 & 32,0
\end{tabular}

researcher then connects them to their scores. The scores are dealt with the focused taxonomy. The presence of multiple components into a table provide componential analysis as shown in Table 1.

Students' participation is taken from their presence on joining tests. The students did the tests sincerely by turning in online student platform Edmodo. Most students are interested to choose education and teaching as their job domain preference. Equal number happens on administration. Those domains relates to their faculties. Responding to grammar learning in the class. It shows that the students score improvement reflects their curiousity to be better on learning so that the gain almost reach those who are interested to education and teaching.

On the other domain, creativity industry shows the lowest participation, although the percentage is good enough. Yet, they need to struggle for getting better result. Their lower-than-half grade and score improvement reflect this statement. Creative industry corresponds to modern and current living atmosphere which collaborate with internet and technology. As the raising of startup by young entrepreneurs, English is highly 
recommended for their success in international relation. English grammar competence offer language skill in formal use struggled by world society in mastering this lingua franca.

The students choosing public relation, consultant, and research as their job domain preference here have respectable attitude. Their score improvements reflect their manner of being courious in getting better score as they did in pre-test.Itis public relation which need to have motivation because their score is lower than half of completeness.

\section{Language and Non-Language Departments Attention on Struggling Grammar}

Their current education is also provided here. It is needed to know whether their education background in the higher education correspond their than half of complete grade than students in the other non-languagemajored departments (in this case Islamic Economy and Business Faculty).

This finding can be tracked. The best average score is by the department applying English as the main subject. It is English Education. Then, all departments in Islamic Education and Teacher Training Faculty participate in Bilingual program. The program invites students in the faculty to be capable in communicating with English together with their formal language like Bahasa Indonesia or Arabic. There are many activities conducted for reaching this goal, including public speaking.It affects much on their consciousness in taking part of English grammar participation. The exposure they get from this program also affects their

Table 2: Average Students' Involvement Based on Departments

\begin{tabular}{lcccc}
\hline \multicolumn{1}{c}{ Departments } & $\begin{array}{c}\text { Number of } \\
\text { students }\end{array}$ & $\begin{array}{c}\text { Participation } \\
\mathbf{( \% )}\end{array}$ & $\begin{array}{c}\text { Grade } \\
\mathbf{( \% )}\end{array}$ & $\begin{array}{c}\text { Score } \\
\text { Improvement }\end{array}$ \\
\hline Islamic Banking & 4 & 96,9 & 58,4 & 7,0 \\
Islamic Accountancy & 5 & 65,0 & 45,3 & 0,8 \\
Islamic Business Management & 8 & 89,1 & 56,1 & 5,5 \\
English Education & 7 & 96,4 & 63,5 & 5,2 \\
Islamic Religious Education & 5 & 95,0 & 60,0 & 6,2 \\
Islamic Indonesian Education & 1 & 100,0 & 74,3 & 7,0 \\
\hline Total & 30 & 542,4 & 357,6 & 31,7
\end{tabular}

motivation to take stance on the language competence learning. This way discovers how much English grammar as part of competency kept in their consciousness in relevance to education variable which they are trying to master. Higher education trains them to be capable on the field they will encounter in the future.

Averagely, the students who are in the departments under supervision of Islamic Education and Teacher Training Faculty have skilful participation. They will be up to the utmost. All departments can cover more competency in English.

The students concentration on Banking, Accountancy, and Business Management need more efforts to reach better score, especially to those five students who are in Islamic Accountancy. This may be affected by their tendency to focus more on numerical application in future career as accountant.

Better English grammar happens to those whose department involve human relation. The departments such as banking and business management combine applying not only numerical 
aspects but also client relation. Their hospitality in dealing with clients needs communication mastery. English as the part of foreign communication is important for them. It is approximately interpreted that they have spirit to be better on next test in every session. This interpretation is proved through foreign language texts. It is proved on the quessionnaire saying $98,2 \%$ agree that English grammar make them easy to comprehend texts. For productivity, 94,6\% agree English grammar as the guidance in composing and arranging words into whole sentence well. The lessons which the researcher tought to

Table 3: Students' Effort to Gain Scores

\begin{tabular}{lcccc}
\hline \multirow{2}{*}{ Departments } & \multicolumn{4}{c}{ Major Lessons } \\
\cline { 2 - 5 } & $\begin{array}{c}\text { Subject- } \\
\text { Verb }\end{array}$ & $\begin{array}{c}\text { Adjective and } \\
\text { Adj. Phrases }\end{array}$ & $\begin{array}{c}\text { Paralel- } \\
\text { ism }\end{array}$ & $\begin{array}{c}\text { Relative } \\
\text { Clause }\end{array}$ \\
\hline Islamic Banking & 1,0 & 0,5 & 1,3 & 2,3 \\
Islamic Accountancy & 0,5 & 0,5 & 0,7 & 2,0 \\
Islamic Business Management & 1,4 & 2,0 & 0,5 & 2,3 \\
English Education & 1,0 & 0,4 & 1,7 & 0,9 \\
Islamic Religious Education & 3,2 & 1,0 & 0,8 & 0,8 \\
Islamic Indonesian Education & 6,0 & 6,0 & 0,0 & 1,0 \\
\hline Total & 13,1 & 10,4 & 4,9 & 9,2
\end{tabular}

their score improvement. It reflects the frequency on how they try to gain their score.

Along with their department, the researcher asked the presence of English lecture. Based on questionnaire distributed, $67,9 \%$ students tought in the class state that they get English lecture up to their current semester while $32,1 \%$ have not. English tutorial class attracted students to strengthen their English competence, especially grammar. For the other students who had not got English lecture, it was their opportunity to have knowledge on English grammar. This is the condition happening in the class. Activity, inquiry, and practice on English grammar learning remains crucial to be performed for exposing better consciousness. They are required for activating their mental awareness while encountering English grammar.

Class is the right environment for ensuring lesson reception by providing theories, strategies, and tips. We, as language teacher or tutor, train students for any applications and possibilities from the lessons in reality or society. It is kind of literacy on the students provide English grammar as the foundation of building sentence up to text. The lesson was started by teaching Subject-Verb Agreement. Then, it was hierarchically continued to adjective and adjective phrases, paralelism, and relative clause. They were the major lessons which could be broken into many issues including word classes, prepositions, gerunds, passive voices, and so on.

Table 3 is provided based on score improvement. Those four major lessons are the goals of comprehending many pieces of issue in English grammar. So, it is the way of learning micro issues into macro (as previously mentioned as major lessons). The effort here proves positive improvement dominantly. The positive values is the indicator of learning process. Students have interest to gain and correct their mistakes as they did in pre-tests. It also reflects that the students are aware on the lessons and doing self-correction.

To explore Table 3, there are many possibilities. There are positive numbers included in every lesson by each student. Do those who get low improvement score not able to gain 
much on their capability in comprehending English grammar, or vice versa? High number of score improvement reflect that students focus on the lessons. They learn and study, so that they are able to gain their scores. They are conscious to become better on learning. Without looking at their pretest whether it has been satisfied or not, they show better comprehension.

The students with low number of improvement reflect two possibilities. First, they have reached good score in pre-test. So, they just need a bit improvement. Even, there may not be any gain, because they have reached maximum score.

Second, low number of improvement show that they need to have more attempts and practices. Such students require guidance to know deeper on grammar issues.

\section{Students' Grammar Monitoring through Expectations on English}

After making relation with job preference and department, the researcher pay attention on broader taxonomy. It is by connecting students'
Questionnaire responses show that $63,3 \%$ students want to be professional with English and 26,7\% just want to get exposure of English competency. Being professional with English is a pleasant finding. They present positive attitude and readiness in learning. It is reflected on the highest rank in the number of students, participation, grade, and improvement. Although the average grade remains far from being optimal, they are attracted to learn. They are councious for being better. It is shown through their score improvement which has highly different with the two other taxonomies.

The high number of students choosing being professional with English should be appreciated. It is needed as long as English remains hold important role in the world which contributes $28,2 \%$ of the global economy (GDP)(Graddol 2006, 62). Moreover, the high attention of being skillful in the world grows number of L2 speakers of English as predicted by David Crystal (Leech 2004, 2078-79). This is affected more in current networking which allow

Table 4: Average Students' Involvement Based on Their Expectations

\begin{tabular}{lcccc}
\hline Expectations with English & $\begin{array}{c}\text { Number of } \\
\text { Students }\end{array}$ & $\begin{array}{c}\text { Partici- } \\
\text { pation (\%) }\end{array}$ & $\begin{array}{c}\text { Grade } \\
\text { (\%) }\end{array}$ & $\begin{array}{c}\text { Score } \\
\text { Improvement }\end{array}$ \\
\hline $\begin{array}{l}\text { So much! I want to be } \\
\text { professional with English }\end{array}$ & 19 & 92,1 & 59,3 & 5,9 \\
$\begin{array}{l}\text { I just want to know and be } \\
\text { able using English }\end{array}$ & 8 & 91,7 & 52,0 & 3,4 \\
$\begin{array}{l}\text { I use English for fulfilling } \\
\text { requirement or obligation } \\
\text { only }\end{array}$ & 3 & 66,7 & 54,1 & 2,0 \\
\hline Total & 30 & 250,4 & 165,4 & 11,3
\end{tabular}

consciousness towards grammar in relation to their expectation with English. Talking about expectation, there is motivation which drives each individual so that it affect someone to confidently do something. Here is the table depicting the situation in the class.

It is a positive response from students towards English. people have more access regionally and internationally. Labelled as the world's lingua franca, it is then applied on prescription and description of English for teaching which students have attempt to comprehend (Seidlhofer 2012, 127).

We may feel regret of the presence of students who use English for fulfilling requirement or obligation only. 
They join the program because it is a must. There is enough pressure to drive them join. However, this program is important for them. English proficiency, especially grammar, is applied in the society. It opens oportunity broader. English provide networking which is up to internationaly use. The presence of this kind of student is only $10 \%$ from the total. It does not affect much.

On the other side, we still appreciate those who are attracted in joining English tutorial sincerely. They remain dominating the class. The chance for living class as the environment for learning is supportive.

Those explanations above depict a piece of English tutorial classes. From the findings, we can know sample condition in the class. There must be various variables in the other classes which require our attention. The crucial thing from comprehending these findings is that the issues here exist. This needs attention so that English tutor can prepare all they need well for teaching. It is not only teaching but also motivating.

Based on the questionnaire taken from the students in the end of meeting, the researcher gets many issues which may be the causes of such condition in the class. Since they were in high school, $73,2 \%$ students state that they have not got English certification yet. It is only $19,6 \%$ have ever joined TOEFL test, 1,8\% TOEIC, and 1,8\% IELTS.

In the issue of English exposure, teacher $(96,4 \%)$ and lecturer $(89,3 \%)$ dominate on introducing them on English grammar. Other people just contribute less than half. They are friends (44,6\%) and parents (21,4\%). Brother, sister, or relative contribute $33,9 \%$. Then, idol is only $1,8 \%$. This finding relates to the reality that the students get English grammar more on academic environment and less in family. It is important for family to have role as part of giving exposure on English because they have more time in home (in their schooling period).

\section{CONCLUSION}

The findings in this research highlight on students consciousness on taking part in English grammar tutorial class. Respecting and appreciating students' participation and effort for making them better are needed in order to support students' without any pressure. Based on the tables above, we can get the point that small number does not reflect inferior. Students in small number may refer to being pioneer. Although they are different than others, they have high number in being improved and active in assessments. They have potential in English grammar.

Those who are less interested in working on academic or education need to have more efforts since English competency is not just limited for particular persons, even it is required for larger networking. Languagemajored departments, whether it is English or not, have better attention than those who are in non-languagemajored departments, although they need to have better score as required in English certifications.

According to the improvements in each major lesson, the students are aware with their pre-tests and able to do self-correction for post-tests. This is kind of consciousness on learning we should be proud. Such hierarchical lessons guide the students to learn grammar carefully from basic up to more complex English sentence. The improving scores as provided in step-bystep lessons should be monitored by educator. This way contributes increasing confidence in teaching so that we realize that every teaching which has done to students shows benefit both transfering knowledge and professionality.

Responding such reality, motivating students on the benefits of English, especially grammar is highly required for keeping them motivated. Most people are attracted to know things they think beneficial for them. It is 
better to include in ELT. Every grammar issue reflects applications in reality. English grammar educator should tell students how each grammar topic is relevant for their life in usages. We need to arouse their curiousity so that they participate, involve, and keep improved in learning process. All things are done for establishing better life among global society, including foreign language competency.

\section{REFERENCES}

Ahmad, Ismail Sheikh, Hazlina Abdullah, \& Muhammad Faizal A Ghani. 2014. "Attitudes and Motivation toward Learning the English Language among Students from Islamic Education System Background: Exploring the Views of Teachers." Journal of Education and Learning (EduLearn) 8 (3): 195. doi:10.11591/edulearn.v8i3.262

Block, David. 2013. "Issues in Language and Identity Research in Applied Linguistics." Estudios de Lingüística Inglesa Aplicada 13 (13): 11-46. doi:10.12795/elia.2013.i13.01

Graddol, David. 2006. English Next. British Council

Jang, Hyungshim. 2008. "Supporting Students' Motivation, Engagement, and Learning during an Uninteresting Activity." Journal of Educational $\begin{array}{llll}\text { Psychology } 100 & \text { (4): } \quad 798-811 .\end{array}$ doi:10.1037/a0012841

Jean, Gladys, \& Daphnée Simard. 2011. "Grammar Teaching and Learning in L2: Necessary, but Boring?" Foreign Language Annals 44 (3): 467-94. doi:10.1111/j.1944-9720.2011.01143.x
Leech, Geoffrey. 2004. "English as a Global Language." The Palgrave Handbook of Economics and Language 36: 2077-80. doi:10.1007/978-1-137-32505-1

Liu, Jin Yu, Yu Jung Chang, Fang Ying Yang, \& Yu Chih Sun. 2011. "Is What I Need What I Want? Reconceptualising College Students' Needs in English Courses for General and Specific/academic Purposes." Journal of English for Academic Purposes 10 (4). Elsevier Ltd: 271-80. doi:10.1016/j.jeap.2011.09.002

Nelson, Graham. 2011. "Natural Language, Semantic Analysis and Interactive Fiction." IF Theory Reader, no. April 2005: 141-88. http://informfiction.org/manual/if_theory.html

Seidlhofer, B. 2012. "Understanding English as a Lingua Franca." International Journal of Applied Linguistics $\quad 77$ (1): 124-28. doi:10.1521/bumc.2013.77.4.413

Serin, Nerguz Bulut, Oğuz Serin, \& Ali Ceylan. 2010. "Affective Characteristics of University Students about English Course and Their Attitude and Thoughts toward the Course." Procedia - Social and Behavioral Sciences 2 (2): 1936-39. doi:10.1016/j.sbspro.2010.03. 1013

Spradley, JP. 2007. Metode Etnografi (trans, 2nd edition). Yogyakarta: Tiara Wacana

Valdez, Gabriela. 2015. "U.S. Higher Education Classroom Experiences of Undergraduate Chinese International Students." Journal of International Students $188 \quad$ (2): $188-200$. http://jistudents.org 